Article

\title{
Cellular Uptake and Photo-Cytotoxicity of a Gadolinium(III)-DOTA-Naphthalimide Complex "Clicked" to a Lipidated Tat Peptide
}

\author{
William I. O’Malley ${ }^{1,+}{ }^{\prime}$, Riccardo Rubbiani ${ }^{2,+}{ }^{+}$, Margaret L. Aulsebrook ${ }^{3}$, Michael R. Grace ${ }^{3}$, \\ Leone Spiccia $^{3}$, Kellie L. Tuck ${ }^{3, *}$, Gilles Gasser ${ }^{2, *}$ and Bim Graham 1,* \\ 1 Monash Institute of Pharmaceutical Sciences, Monash University, Parkville VIC 3163, Australia; \\ william.o'malley@monash.edu \\ 2 Department of Chemistry, University of Zurich, Winterthurerstrasse 190, Zurich CH-8057, Switzerland; \\ riccardo.rubbiani@chem.uzh.ch \\ 3 School of Chemistry, Monash University, Clayton VIC 3800, Australia; \\ margaret.aulsebrook@monash.edu (M.L.A.); mike.grace@monash.edu (M.R.G.); \\ leone.spiccia@monash.edu (L.S.) \\ * Correspondence: kellie.tuck@monash.edu (K.L.T.); gilles.gasser@chem.uzh.ch (G.G.); \\ bim.graham@monash.edu (B.G.); Tel.: +61-3-9905-4510 (K.L.T.); \\ +41-44-635-46-30 (G.G.); +61-3-9903-9706 (B.G.) \\ + These authors contributed equally to this work.
}

Academic Editor: Wiktor Szymański

Received: 12 December 2015 ; Accepted: 2 February 2016 ; Published: 5 February 2016

\begin{abstract}
A new bifunctional macrocyclic chelator featuring a conjugatable alkynyl-naphthalimide fluorophore pendant group has been prepared and its $\mathrm{Gd}(\mathrm{III})$ complex coupled to a cell-penetrating lipidated azido-Tat peptide derivative using $\mathrm{Cu}(\mathrm{I})$-catalysed "click" chemistry. The resulting fluorescent conjugate is able to enter CAL-33 tongue squamous carcinoma cells, as revealed by confocal microscopy, producing a very modest anti-proliferative effect $\left(\mathrm{IC}_{50}=93 \mu \mathrm{M}\right)$. Due to the photo-reactivity of the naphthalimide moiety, however, the conjugate's cytotoxicity is significantly enhanced $\left(\mathrm{IC}_{50}=16 \mu \mathrm{M}\right)$ upon brief low-power UV-A irradiation.
\end{abstract}

Keywords: cell-penetrating peptide; fluorescence; gadolinium complex; photo-cytotoxicity; theranostic

\section{Introduction}

There continues to be much interest in the development of molecular imaging agents, including ones that can be detected by more than one imaging modality ("multi-modal imaging agents") [1-5]. This is particularly so within the field of oncology, where imaging agents are used extensively for the screening, diagnosis, staging, planning of treatment, post-treatment assessment and surveillance of cancer [6,7]. Another area that has seen rapid growth over the last decade is the development of agents that can be used for both imaging and therapy ("theranostics"), allowing for image-guided drug delivery, in vivo detection of drug release/activation, and/or monitoring of patient's response to therapy [8-10]. Designs range from small molecules and (bio)conjugates [11] through to multi-functional nanoparticulate systems $[12,13]$.

The most advanced theranostic designs are engineered to be stimuli-responsive, with activation of therapeutic activity/drug release occurring in response to endogenous triggers (e.g., $\mathrm{pH}$ change, hypoxia, elevated enzyme activity) or external stimuli (e.g., heat, light). This allows for controlled dosing and/or reduced exposure of non-diseased cells/tissue to cytotoxic species [14,15]. The development of photo-responsive systems, in particular, has received considerable attention, since light, as a stimulus, is generally non-invasive and can be readily manipulated, enabling 
drug activation/release to be controlled both spatially and temporally with extreme precision. Photo-responsiveness is often achieved by loading bioactive cargo into carrier (nano)materials that are amenable to dissociation/structural change upon exposure to light [16-18]. Alternatively, light-activated pro-drugs may be employed in the construction of photo-responsive theranostic designs. These include photo-sensitisers, which generate cytotoxic singlet oxygen $\left({ }^{1} \mathrm{O}_{2}\right)$ in response to light and form the basis of photo-dynamic therapy (PDT) [19-21], and photo-activated chemotherapeutic (PACT) agents, which induce cell death through mechanisms such as light-mediated ligand ejection, DNA crosslinking and uncaging [22-27]. As an added benefit, many PDT and PACT agents are luminescent, providing a ready means of detection [28-30].

The development of increasingly elaborate and sophisticated multi-modal imaging agent and theranostic designs, including photo-responsive ones, has been aided by the advent of "bio-orthogonal" chemistries, such as the $\mathrm{Cu}(\mathrm{I})$-catalysed azide-alkyne cycloaddition reaction ("click reaction") $[31,32]$ and its Cu-free variant-strain-promoted azide-alkyne cycloaddition (SPAAC) [33,34]. These allow for the late-stage introduction of moieties into highly functionalised molecules (small molecules, peptides, proteins) [35-38] and nanoparticles [39-41], as well as the controlled stepwise elaboration of hetero-multifunctional scaffolds [42-44], without the need for complex protection group strategies. The widespread adoption of bio-orthogonal labelling technologies in the biological and biomedical sciences has also seen an expanding toolbox of "clickable" compounds (fluorophores, cross-linkers, macrocyclic chelators, etc.) become available to researchers interested in multi-functional imaging and therapeutic agents. Indeed, many such "building blocks" are now commercially available.

We have a particular interest in the development of metal complex-based agents for imaging and therapy, including photo-cytotoxic complexes for potential application as new PDT and PACT agents [45-52]. During the course of our work, a number of "clickable" metal complexes/chelators have been developed and employed in the synthesis of peptide conjugates with tumour-targetting, cell-penetrating and/or organelle-specific localising properties [53-56]. Additionally, we have incorporated alkyne-bearing metal complexes into proteins via click conjugation to unnatural amino acids to facilitate protein structural investigations [57-59]. Many other research groups have likewise reported alkyne- and azide-bearing metal complexes/chelators for a range of biological and biomedical applications [60-64].

As part of an effort to generate new photo-activated theranostics and multi-modal imaging agents, we have now developed a new macrocyclic gadolinium(III) complex of a 1,4,7,10-tetraazacyclodocane1,4,7,10-tetraacetic acid (DOTA) derivative featuring a conjugatable alkynyl-napthalimide pendant. Naphthalimide derivatives are widely employed as fluorescent dyes and are known to be photo-reactive [65-71], while Gd(III)-DOTA-type complexes are well-established MRI contrast agents [72-74]. To demonstrate its utility, the complex has been conjugated to a "model" peptide-a lipidated, azide-bearing derivative of the cell-penetrating "Tat" peptide, derived from the HIV-1 "Trans-Activator of Transcription" protein [75]. We show that the "clicked" naphthalimide moiety can be used for fluorescence tracking and results in a photo-cytotoxic effect when cellular entry of the complex is facilitated by conjugation to the Tat peptide.

\section{Results and Discussion}

\subsection{Synthesis of Ligand and Gd(III) Complexes}

The synthesis of the ligand, L, commenced with a condensation reaction between commercially-available 4-bromo-1,8-naphthalic anhydride and N-Boc-1,2-ethylenediamine, followed by a Sonogashira reaction of the product (1) with trimethylsilyl (TMS) acetylene to install a TMS-protected alkyne group in place of the bromo substituent (Scheme 1). Following Boc-deprotection of 2 with trifluoroacetic acid (TFA), the exposed amine of 3 was reacted with bromoacetyl bromide to produce the bromoacetamide derivative, 4 . Compound 4 was subsequently coupled to tert-butyl-protected 1,4,7,10-tetraazacyclododecane-1,4,7-triacetic acid ( ${ }^{\mathrm{t}} \mathrm{Bu}_{3} \mathrm{DO} \mathrm{A}$ ) [76]. Lastly, the 
TMS and ${ }^{\mathrm{t}} \mathrm{Bu}$ groups were removed using KF and TFA, respectively, to yield L, which was purified by preparative HPLC.

The Gd(III) complex, Gd-L, was prepared by heating a neutral (pH 6.5-7.5) aqueous solution of the ligand with two equiv. of gadolinium(III) acetate for $2 \mathrm{~h}$, after which time LC-MS analysis indicated near-quantitative complexation. Preparative HPLC was then used to purify the complex to $>95 \%$ purity.

As an initial test, Gd-L was conjugated to 3-azido-1-propanol as a model azide in aqueous solution. $\mathrm{CuSO}_{4}$ (0.1 equiv.) was utilised as the copper source, sodium ascorbate (1 equiv.) as the reducing agent and tris(3-hydroxypropyl-triazolylmethyl)amine (THTPA) (0.2 equiv.) as a $\mathrm{Cu}(\mathrm{I})$-stabilising ligand [77,78]. After stirring overnight, conversion to the clicked product was near-quantitative according to LC-MS analysis. The complex was again isolated in $>95 \%$ purity following preparative HPLC.

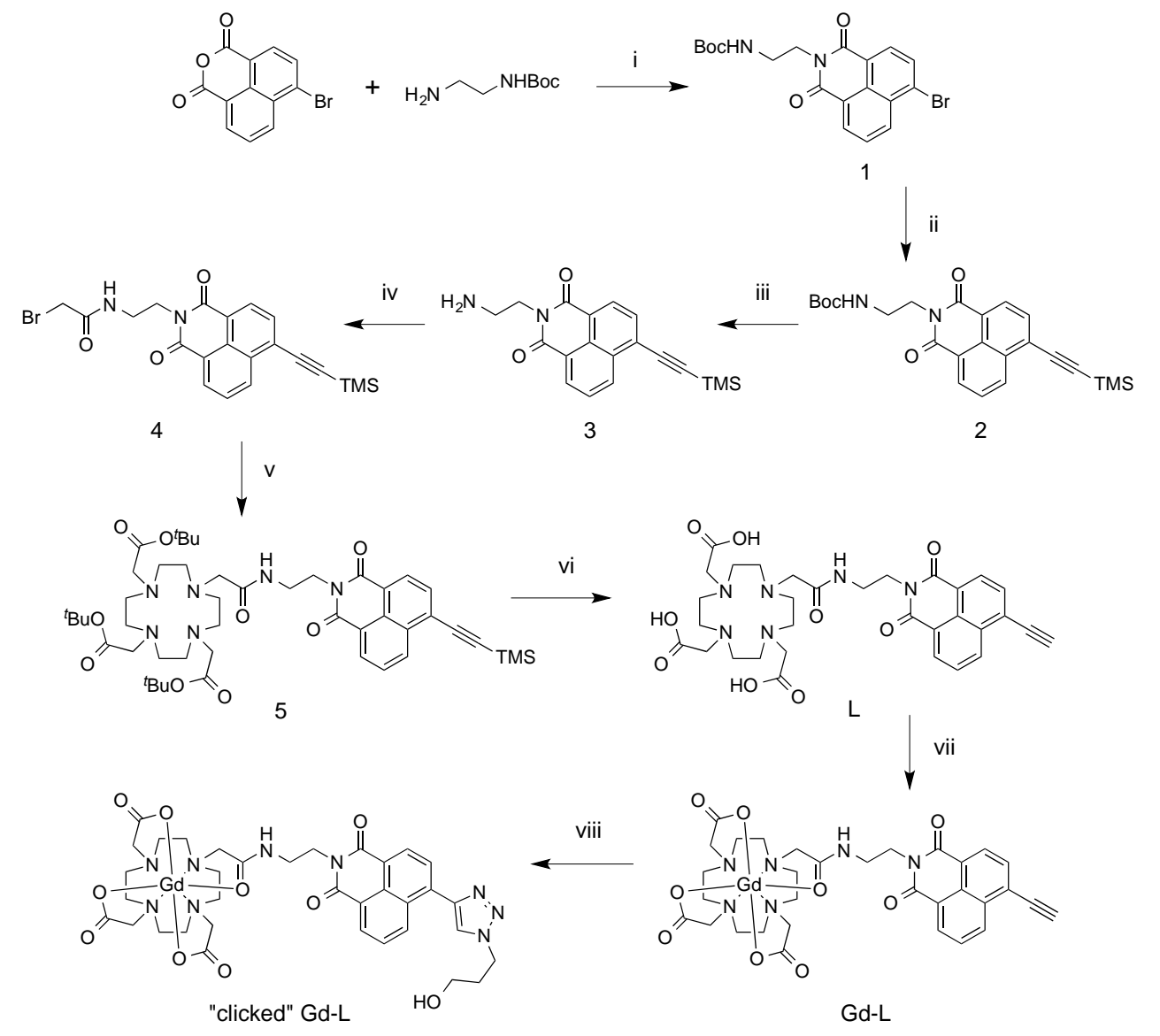

Scheme 1. Synthesis of ligand and $\mathrm{Gd}(\mathrm{III})$ complexes. (i) $\mathrm{DMF}, 80{ }^{\circ} \mathrm{C}$, overnight $(\mathrm{O} / \mathrm{N}), 91 \%$; (ii) TMS acetylene, $\mathrm{Pd}\left(\mathrm{PPh}_{3}\right)_{2} \mathrm{Cl}_{2}, \mathrm{CuI}, \mathrm{Et}_{3} \mathrm{~N}, \mathrm{THF}, \mathrm{N}_{2}$ atmosphere, $\mathrm{RT}, 3 \mathrm{~h}, 48 \%$; (iii) TFA, DCM, RT, $4 \mathrm{~h}, 96 \%$; (iv) bromoacetyl bromide, $\mathrm{Na}_{2} \mathrm{CO}_{3}$, acetone, RT, $3 \mathrm{~h}, 59 \%$; (v) ${ }^{\mathrm{t}} \mathrm{Bu}_{3} \mathrm{DO}_{3} \mathrm{~A}$.HBr, DIPEA, ACN, reflux, O/N, 81\%; (vi) (a) KF, $\mathrm{H}_{2} \mathrm{O} / \mathrm{ACN}, \mathrm{RT}, 2 \mathrm{~h}$; (b) TFA, DCM, RT, O/N, 71\% (over two steps); (vii) $\mathrm{Gd}(\mathrm{OAc})_{3}$, water $/ \mathrm{ACN}, 70{ }^{\circ} \mathrm{C}, 2 \mathrm{~h}$, quant. (53\% isolated); (viii) 3-azido-1-propanol, $\mathrm{CuSO}_{4}$, sodium ascorbate, THPTA, water/ACN, $\mathrm{pH} 7, \mathrm{RT}, \mathrm{O} / \mathrm{N}$, quant. (47\% isolated).

\subsection{Photo-Physical Properties of Complexes}

The spectral properties of the two Gd(III) complexes were measured in aqueous solution buffered at pH 7.4 with $100 \mathrm{mM}$ HEPES. Table 1 summarises the data, while absorbance and fluorescence emission spectra of the complexes are shown in Figure 1.

Click conjugation of the Gd-L complex is associated with a slight bathochromic shift $(6 \mathrm{~nm})$ in the absorbance band arising from ${ }^{*} \pi-\pi^{*}$ transitions within the naphthalimide group. A much larger shift 
(54 nm) is observed for the fluorescence emission band and the fluorescence quantum yield is increased by $c a$. 70\%. These findings are in accordance with those reported for a simple $N$-ethyl naphthalimide derivative bearing an alkyne at the 8-position [79].

Table 1. Photo-physical data for Gd(III) complexes measured in 100 mM HEPES, pH 7.4 (298 K).

\begin{tabular}{ccccc}
\hline Complex & $\begin{array}{c}\text { Absorption } \lambda_{\max } \\
\left(\varepsilon\left(\mathbf{M}^{-1} \mathbf{c m}^{-1}\right)\right)\end{array}$ & Emission $\lambda_{\max }$ & $\Phi^{\mathbf{a}(\mathbf{\%})}$ & $\begin{array}{c}\text { Brightness }(\varepsilon \times \Phi / \mathbf{1 0 0 0} \\
\left.\left(\mathbf{M}^{-1} \mathbf{c m}^{-1}\right)\right)\end{array}$ \\
\hline Gd-L & $356(22,500)$ & 417 & $35 \%$ & 7.9 \\
"Clicked" Gd-L & $362(19,200)$ & 471 & $59 \%$ & 11.3 \\
\hline \multicolumn{5}{c}{}
\end{tabular}

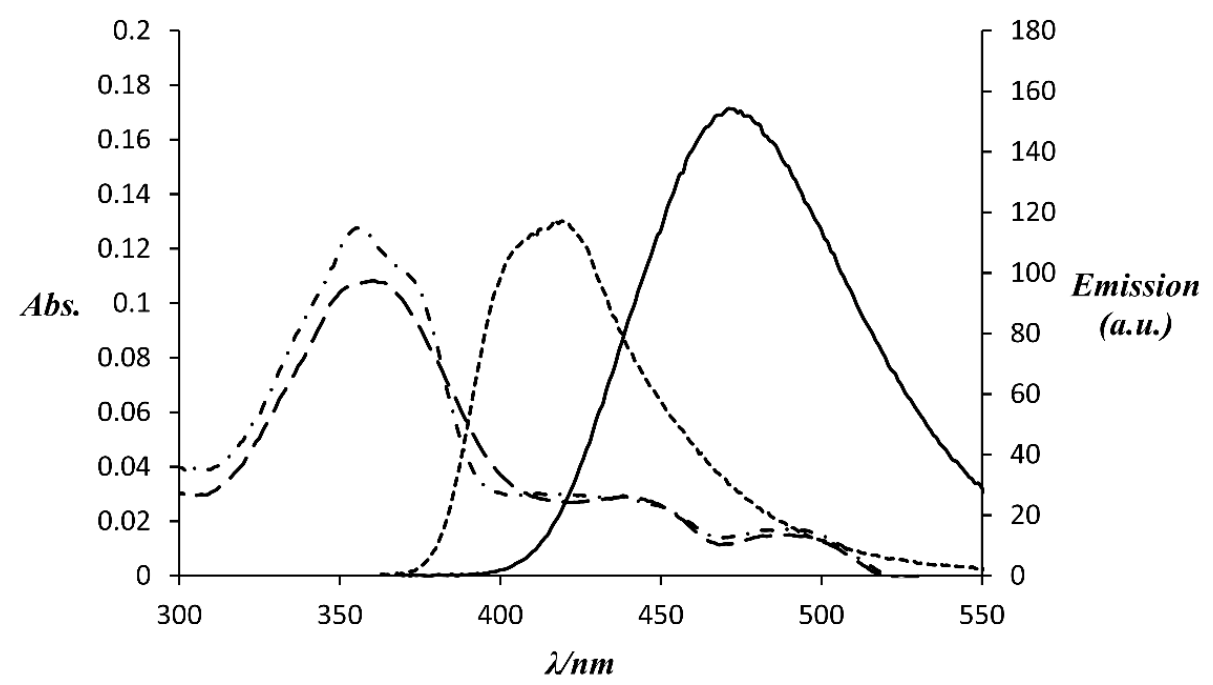

Figure 1. Absorbance and fluorescence emission spectra of $\mathrm{Gd}(\mathrm{III})$ complexes $(5 \mu \mathrm{M})$ in $100 \mathrm{mM}$ HEPES, pH 7.4 (298 K). Dot-dashed line: absorbance of Gd-L, dotted line: emission of Gd-L excited at $356 \mathrm{~nm}$, dashed line: absorbance of "clicked" Gd-L, solid line: emission of "clicked" Gd-L excited at $362 \mathrm{~nm}$.

\subsection{Conjugation of Complex to Lipidated Tat Peptide}

To demonstrate its utility, the Gd-L complex was ligated to a derivative of the cell-penetrating Tat peptide featuring a myristic acid tail at its $\mathrm{N}$-terminus (to aid with cellular uptake) and an internal azido-L-lysine residue (Figure 2). We have previously attached a luminescent rhenium(I) complex to this lipidated peptide and visualised uptake of the resulting conjugate into cells via fluorescence microscopy [55]. Stirring the peptide with Gd-L in the presence of $\mathrm{CuSO}_{4}$, sodium ascorbate and THPTA at room temperature overnight led to essentially quantitative conversion, as judged by LC-MS analysis. The product was isolated in $90 \%$ purity following preparative HPLC.

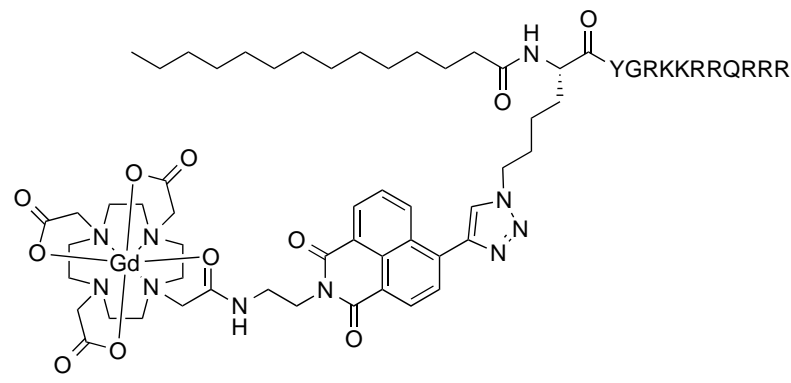

Figure 2. Structure of Gd-L-bearing myristylated Tat peptide conjugate. 


\section{4. (Photo-)cytotoxicity of Complexes and Conjugate}

The cytotoxic properties of Gd-L, "clicked" Gd-L and the Gd-L-Tat peptide conjugate were assessed on CAL-33 tongue squamous carcinoma cells, either in the dark or combined with short exposure to a low-power dose of UV-A radiation $\left(350 \mathrm{~nm}, 2.58 \mathrm{~J} \cdot \mathrm{cm}^{-2}, 10 \mathrm{~min}\right)$. As the results in Table 2 indicate, the Gd-L and "clicked" Gd-L complexes exerted essentially no cytotoxic effect under either of these conditions, with measured $\mathrm{IC}_{50}$ values $>100 \mu \mathrm{M}$ in all cases. The Tat conjugate also produced only a very modest anti-proliferative effect when incubated with cells in the dark ( $\mathrm{IC}_{50} \approx 93 \mu \mathrm{M}$ ). However, a six-fold enhancement in cytotoxicity $\left(\mathrm{IC}_{50} \approx 16 \mu \mathrm{M}\right)$ was observed when the conjugate was exposed to UV-A radiation (see also Figure 3). These results reflect, first of all, that the myristylated Tat peptide aids considerably with cellular uptake $[55,81]$. Secondly, the observed photo-cytotoxicity of the conjugate is consistent with previous reports of the photo-reactivity of naphthalimide derivatives towards biological molecules, including proteins and nucleic acids [65-71].

Table 2. Anti-proliferative effects of the Gd(III) complexes and Tat peptide conjugate on CAL-33 cancer cells in the dark and upon light irradiation at $350 \mathrm{~nm}$ for $10 \mathrm{~min}\left(2.58 \mathrm{~J} \cdot \mathrm{cm}^{-2}\right)$.

\begin{tabular}{cccc}
\hline Compound & IC $_{\mathbf{5 0}}$ (Dark) $^{\mathbf{a}}(\boldsymbol{\mu M})$ & IC $_{\mathbf{5 0}}$ (UV-A) ${ }^{\mathbf{a}}(\mu \mathbf{M})$ & PI $^{\mathbf{b}}$ (x-Fold) \\
\hline Gd-L & $>100$ & $>100$ & n.a. \\
“clicked" Gd-L & $>100$ & $>100$ & n.a. \\
Gd-L-Tat conjugate & $93 \pm 3$ & $16 \pm 6$ & 5.8 \\
\hline
\end{tabular}

a expressed as mean \pm standard error of independent experiments; ${ }^{\mathrm{b}} \mathrm{PI}=$ photo-toxic index $=\mathrm{IC}_{50}(\mathrm{UV}-\mathrm{A}) / \mathrm{IC}_{50}$ (dark). n.a. = not applicable.

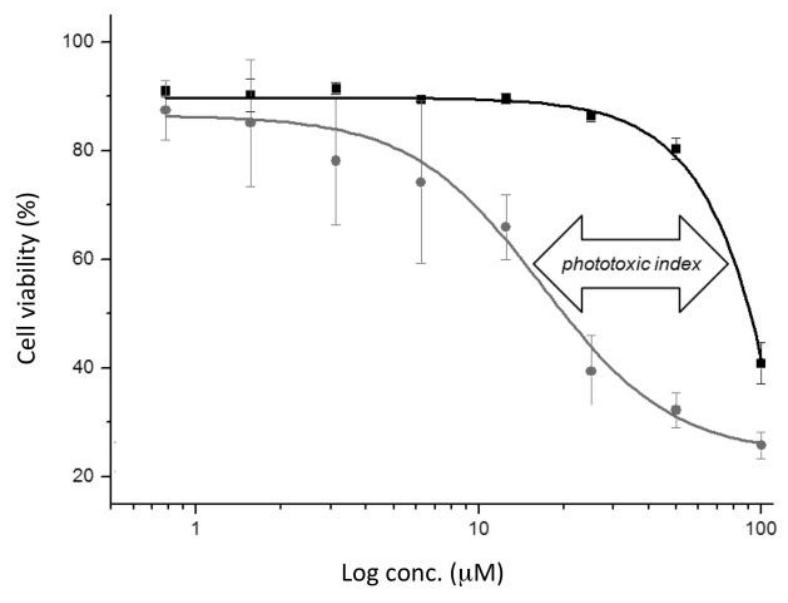

Figure 3. Dose-response curves for the anti-proliferative effect of Gd-L-Tat peptide conjugate on CAL-33 cells in the dark (black line) and upon UV-A irradiation (at $350 \mathrm{~nm}$ for $10 \mathrm{~min}, 2.58 \mathrm{~J} \cdot \mathrm{cm}^{-2}$; grey line).

\subsection{Cellular Uptake of Complexes and Conjugates}

The ability of the two Gd(III) complexes and the Tat conjugate to enter CAL-33 cells was assessed using confocal fluorescence microscopy (Figure 4). Although the optimal excitation and emission wavelengths for the naphthalimide fluorophore are 356 and $417 \mathrm{~nm}$ for Gd-L and 362 and $471 \mathrm{~nm}$ for "clicked" Gd-L, respectively (Table 1), the compounds could also be reliably detected using the microscope's "hybrid 1 red wavelength" channel (excitation: $405 \mathrm{~nm}$; emission: 600-800 nm) because of the brightness of the naphthalimide fluorophore, combined with the broadness of its absorption and emission peaks. For cells incubated with "clicked" Gd-L, only extremely weak fluorescence was observed (panels $2 b$ and $3 b$ ), while cells treated with Gd-L were essentially non-fluorescent (panels $2 \mathrm{c}$ and $3 \mathrm{c}$ ), indicating that these complexes are not able to enter CAL-33 cells. In contrast, for 
cells incubated with the Gd-L-Tat peptide conjugate there was clear evidence of uptake and localisation within the cytoplasmic regions of the cells (panel 3d). This is consistent with the results of previous studies, which have shown that myristylated Tat is an effective cell-penetrating agent [55,81]. The experiments were performed at $100 \mu \mathrm{M}$, a concentration that resulted in a clear Gd-L-Tat signal. At this dose, it was possible to observe the early stages of induced cellular stress, in good agreement with the cytotoxicity investigation. It is worthwhile noting that, besides cytosolic uptake, Gd-L-Tat also displayed some punctate accumulation in regions ascribable to the cell nucleoli (panels $2 \mathrm{~d}$ and $3 \mathrm{~d}$ ). Overall, the confocal microscopy results help to rationalise the cytotoxicity data: the conjugate is the only compound that exerts a cytotoxic effect because it is the only compound to enter the CAL-33 cells.

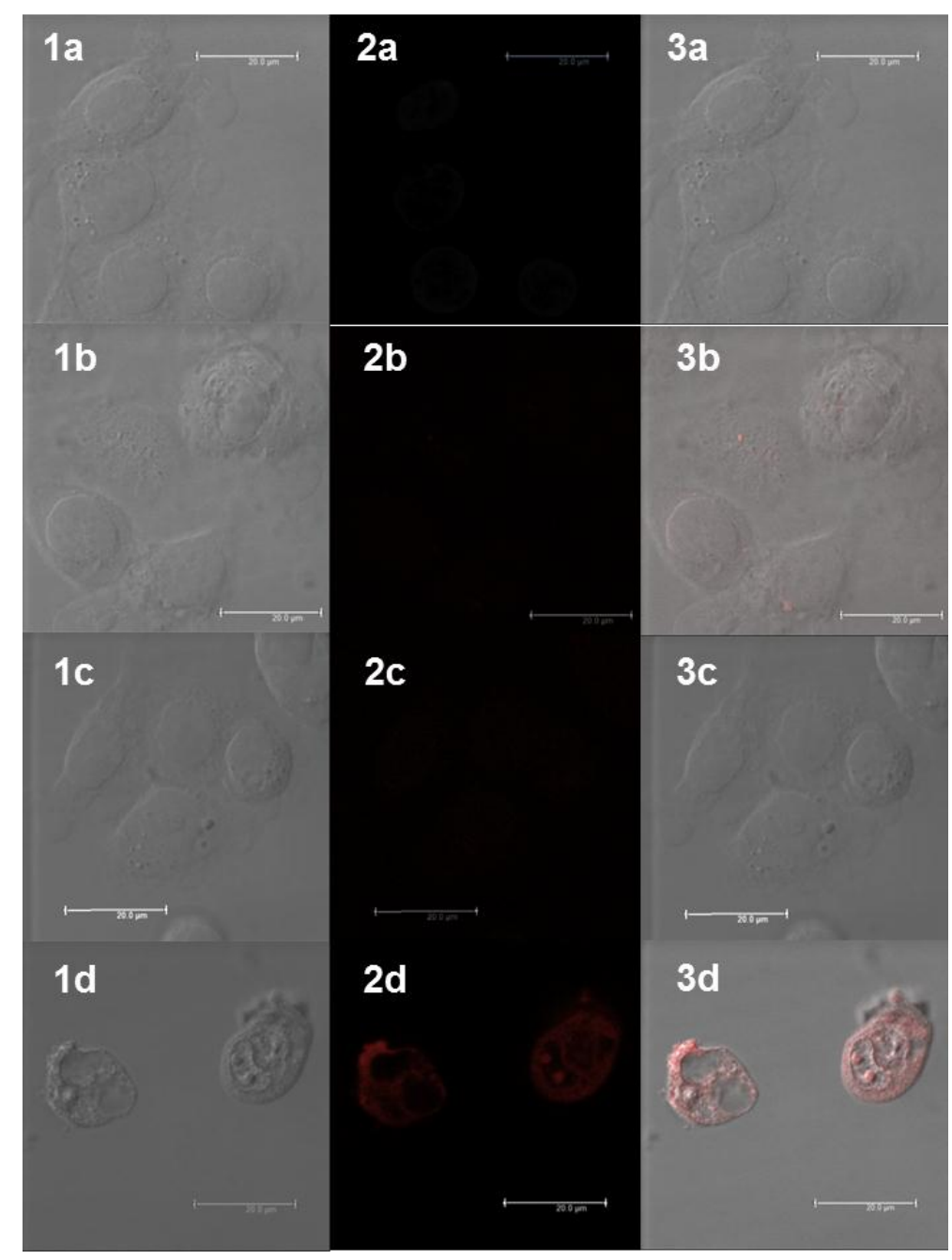

Figure 4. Confocal fluorescence microscopic images of CAL-33 cells incubated with Gd(III) complexes or conjugate for $4 \mathrm{~h}$ : (1a) DIC (differential interference contrast) image of the untreated Cal-33 cells; (2a) visualisation of background fluorescence in untreated CAL-33 cells using the excitation/emission wavelength settings (hybrid 1 channel) employed for detection of the Gd(III) compounds; (3a) merged image of the DIC and hybrid 1 channel images of untreated cells; (1) DIC image of the CAL-33 cells treated with $100 \mu \mathrm{M}$ of "clicked" Gd-L; (2b) visualisation of "clicked" Gd-L in cells; (3b) merged image of the DIC and hybrid 1 channel images of cells treated with "clicked" Gd-L; (1c) DIC image of the CAL-33 cells treated with $100 \mu \mathrm{M}$ of Gd-L; (2c) visualisation of Gd-L in cells; (3c) merged image of the DIC and hybrid 1 channel images of cells treated with Gd-L; (1d) DIC image of the CAL-33 cells treated with $100 \mu \mathrm{M}$ of Gd-L-Tat peptide conjugate; (2d) visualisation of Gd-L-Tat peptide conjugate in cells; (3d) merged image of the DIC and hybrid 1 channel images of cells treated with Gd-L-Tat peptide conjugate. The scale bars represent $20 \mu \mathrm{m}$. 


\section{Experimental Section}

\subsection{Materials and Methods}

All chemicals were purchased from Sigma-Aldrich Pty (St. Louis, MO, USA), Matrix Scientific (Columbia, SC, USA), or Merck Group Ltd (Darmstadt, Germany) and used without purification. 1,4,7,10-Tetraazacyclododecane-1,4,7-triacetic acid ( ${ }^{\mathrm{t}} \mathrm{Bu}_{3} \mathrm{DO} \mathrm{A}$.HBr) [76] and tris(3-hydroxypropyltriazolylmethyl)amine (THTPA) [77,78], were synthesised as per reported literature procedures. All solvents were reagent, analytical or HPLC grade.

Flash chromatography was carried out using Merck 38 Silica gel 60, 230-400 mesh ASTM. Thin layer chromatography (TLC) was performed on Merck Silica Gel 60 F254 plates. TLC plates were visualised using a UV lamp at $254 \mathrm{~nm}$ or through the use of $\mathrm{KMnO}_{4}$ or ninhydrin staining agent.

Elemental analyses were performed by the Campbell Microanalytical Laboratory, Otago, New Zealand.

${ }^{1} \mathrm{H}$ and ${ }^{13} \mathrm{C}$ nuclear magnetic resonance (NMR) spectra were recorded using an Avance III Nanobay $400 \mathrm{MHz}$ Bruker spectrometer (Billerica, MA, USA) coupled to the BACS 60 automatic sample changer at $400.13 \mathrm{MHz}$ and $100.61 \mathrm{MHz}$, respectively. Data acquisition and processing was managed using Topspin software package version 3. Additional processing was handled with MestReNova software (PC). Chemical shifts $(\delta)$ were measured in parts per million, referenced to an internal standard of residual solvent. Spectroscopic data are given using the following abbreviations: s, singlet; $\mathrm{d}$, doublet; $\mathrm{dd}$, doublet of doublets; ddd, doublet of doublet of doublets; $\mathrm{dt}$, doublet of triplets; $\mathrm{t}$, triplet; $\mathrm{m}$, multiplet; J, coupling constant.

Analytical high-performance liquid chromatography (HPLC) was carried out on an Agilent 1260 series modular HPLC (Santa Clara, CA, USA) equipped with the following modules: G1312B binary pump, G1316A thermostated column compartment equipped with an Agilent Eclipse Plus C18 $3.5 \mu \mathrm{m}$, $4.6 \times 100 \mathrm{~mm}$ column and a G1312B diode array detector. The following elution protocol was used: 0-10 min, gradient from $5 \%$ solvent $B / 95 \%$ solvent $A$ to $100 \%$ solvent $B$ (solvent $A=99.9 \% \mathrm{H}_{2} \mathrm{O}$, $0.1 \%$ TFA, and solvent $\mathrm{B}=99.9 \%$ acetonitrile (ACN), $0.1 \%$ TFA, except in the case of the analysis of $\mathrm{Gd}$ complexes, where solvent $\mathrm{A}=99.9 \% \mathrm{H}_{2} \mathrm{O}, 0.1 \%$ formic acid, and solvent $\mathrm{B}=99.9 \% \mathrm{ACN}, 0.1 \%$ formic acid); flow rate $=1 \mathrm{~mL} \cdot \mathrm{min}^{-1}$.

Preparative HPLC purification was carried out on an Agilent 1260 modular Prep HPLC equipped with the following modules: G1361A prep pump, G2260A prep automatic liquid sampler, G1364B fraction collector, G1315D diode array detector, and a Luna C8 $5 \mu \mathrm{m}, 100 \AA$ AXIA, $250 \times 21.2 \mathrm{~mm}$ column. The following elution protocol was used: $0-5 \mathrm{~min}, 100 \%$ solvent $\mathrm{C} ; 5-30 \mathrm{~min}$, gradient from $100 \%$ solvent $\mathrm{A}$ to $20 \%$ solvent $\mathrm{C} / 80 \%$ solvent $\mathrm{D}$ (solvent $\mathrm{C}=99.9 \% \mathrm{H}_{2} \mathrm{O}, 0.1 \%$ formic acid; solvent $\mathrm{D}=99.9 \% \mathrm{ACN}, 0.1 \%$ formic acid); flow rate $=20 \mathrm{~mL} \cdot \mathrm{min}^{-1}$.

High-resolution mass spectrometric (HRMS) analyses were performed on a Waters LCT TOF LC-MS mass spectrometer (Milford, MA, USA) coupled to a 2795 Alliance Separations module. All data were acquired and mass corrected via a dual-spray Leucine Enkephaline reference sample. Mass spectra were generated by averaging the scans across each peak and background subtracted of the TIC. Acquisition and analysis were performed using the MassLynx software version 4.1. The mass spectrometer conditions were as follows: electrospray ionisation (ESI) mode, desolvation gas flow of $550 \mathrm{~L} \cdot \mathrm{h}^{-1}$, desolvation temperature of $250{ }^{\circ} \mathrm{C}$, source temperature of $110^{\circ} \mathrm{C}$, capillary voltage of $2400 \mathrm{~V}$, sample cone voltage of $60 \mathrm{~V}$, scan range acquired between 100-1500 m/z, one sec scan times and internal reference ions for positive ion mode (Leucine Enkephaline) of 556.2771.

Liquid chromatography-mass spectrometry (LC-MS) was performed using an Agilent 6100 Series Single Quad LC-MS coupled to an Agilent 1200 Series HPLC with the following mass spectrometer conditions: multimode-ESI mode, $300{ }^{\circ} \mathrm{C}$ drying gas temperature, $200{ }^{\circ} \mathrm{C}$ vaporising temperature, capillary voltage of $2000 \mathrm{~V}$ (positive), capillary voltage of $4000 \mathrm{~V}$ (negative), scan range between $100-1000 \mathrm{~m} / \mathrm{z}$ with an $0.1 \mathrm{~s}$ step size and a $10 \mathrm{~min}$ acquisition time. 
Analysis of the peptide conjugates was performed on a Shimadzu modular LC-MS system (Kyoto, Japan) equipped with the following modules: LC-20AD liquid chromatograph system, SPD-M20A diode array detector, CTO-20A column oven equipped with a Luna 3 micron C8(2) $3 \mu \mathrm{m}$, $100 \AA, 100 \times 2.0 \mathrm{~mm}$ column and a LC-MS-2020 system, operating in positive mode with an $\mathrm{m} / \mathrm{z}$ scan range of 200-2000.

Absorbance spectra were recorded on a Varian Cary 50 Bio UV-Vis spectrophotometer (Palo Alto, CA, USA) using a $1 \mathrm{~cm}$-path length quartz cuvette. Fluorescence emission spectra were acquired using a Varian Cary Eclipse fluorescence spectrophotometer using a $1 \mathrm{~cm}$-path length quartz cuvette.

\subsection{Synthetic Procedures}

\subsection{1. tert-Butyl 2-(6-bromo-1,3-dioxo-1H-benzo[de]isoquinolin-2(3H)-yl)ethylcarbamate (1)}

4-Bromo-1,8-napthalic anhydride (3.00 g, $10.8 \mathrm{mmol})$ and $\mathrm{N}$-(tert-butoxycarbonyl)-1, 2-ethylenediamine $(1.91 \mathrm{~g}, 11.9 \mathrm{mmol})$ were dissolved in DMF $(30 \mathrm{~mL})$ and stirred at $80{ }^{\circ} \mathrm{C}$ overnight $(\mathrm{O} / \mathrm{N})$. The solution was then allowed to cool to room temperature (RT), before being poured into ice-cold water to produce a yellow precipitate, which was collected via vacuum filtration, washed several times with cold $\mathrm{H}_{2} \mathrm{O}$ and dried in a vacuum desiccator overnight. Yield: $4.12 \mathrm{~g}, 91 \% .{ }^{1} \mathrm{H}-\mathrm{NMR}$ $\left(\right.$ DMSO- $\left._{6}\right) \delta 8.62-8.39(\mathrm{~m}, 2 \mathrm{H}), 8.26(\mathrm{~d}, J=7.2 \mathrm{~Hz}, 1 \mathrm{H}), 8.17(\mathrm{~d}, J=7.5 \mathrm{~Hz}, 1 \mathrm{H}), 7.95(\mathrm{t}, J=7.4 \mathrm{~Hz}, 1 \mathrm{H})$, $6.87(\mathrm{~s}, 1 \mathrm{H}), 4.10(\mathrm{~s}, 2 \mathrm{H}), 3.25(\mathrm{~d}, J=4.1 \mathrm{~Hz}, 2 \mathrm{H}), 1.19(\mathrm{~s}, 9 \mathrm{H}) .{ }^{13} \mathrm{C}-\mathrm{NMR}\left(\mathrm{DMSO}-d_{6}\right) \delta 163.05,163.00$, 155.77, 132.36, 131.38, 131.25, 130.76, 129.71, 128.83, 128.71, 128.39, 122.99, 122.23, 77.46, 37.63, 28.04. LC-MS (ESI): $m / z 319.21[\mathrm{M}-\mathrm{Boc}+\mathrm{H}]^{+}(100 \%)$. Analytical HPLC: $89 \%$ purity $(254 \mathrm{~nm})$.

3.2.2. tert-Butyl 2-(1,3-dioxo-6-((trimethylsilyl)ethynyl)-1H-benzo[de]-isoquinolin-2(3H)-yl)ethylcarbamate (2)

Compound 1 (4.00 g, $9.54 \mathrm{mmol}$ ), TMS acetylene (1.12 g, $1.49 \mathrm{~mL}, 11.5 \mathrm{mmol}), \mathrm{Pd}\left(\mathrm{PPh}_{3}\right)_{2} \mathrm{Cl}_{2}$ ( $334 \mathrm{mg}, 0.48 \mathrm{mmol}), \mathrm{CuI}(182 \mathrm{mg}, 0.95 \mathrm{mmol})$ and $\mathrm{Et}_{3} \mathrm{~N}(2.90 \mathrm{~g}, 4.00 \mathrm{~mL}, 28.6 \mathrm{mmol})$ were all dissolved in dry THF $(100 \mathrm{~mL})$ and stirred at RT for $2 \mathrm{~h}$ under a $\mathrm{N}_{2}$ atmosphere. The solution was combined with $\mathrm{H}_{2} \mathrm{O}(100 \mathrm{~mL})$ and extracted with dichoromethane $(\mathrm{DCM})(3 \times 100 \mathrm{~mL})$. The combined extracts were dried over $\mathrm{MgSO}_{4}$ and evaporated in vacuo to produce a dark brown-black solid, which was subjected to silica gel chromatography $\left(10 \%\right.$ EtOAc in DCM, ) to yield the product as a pale yellow solid $\left(R_{\mathrm{f}}=0.6\right)$. Yield: $1.99 \mathrm{~g}, 48 \% .{ }^{1} \mathrm{H}-\mathrm{NMR}\left(\mathrm{DMSO}-d_{6}\right) \delta 8.52(\mathrm{dd}, J=13.6,7.8 \mathrm{~Hz}, 2 \mathrm{H}), 8.39(\mathrm{~d}, J=7.6 \mathrm{~Hz}, 1 \mathrm{H}), 7.91$ $(\mathrm{t}, J=8.0 \mathrm{~Hz}, 2 \mathrm{H}), 6.80(\mathrm{t}, J=6.2 \mathrm{~Hz}, 1 \mathrm{H}), 4.13(\mathrm{t}, J=5.8 \mathrm{~Hz}, 2 \mathrm{H}), 3.27(\mathrm{dd}, J=11.6,5.9 \mathrm{~Hz}, 2 \mathrm{H}), 1.21$ (s, 9H), 0.34 (s, 9H). ${ }^{13} \mathrm{C}-\mathrm{NMR}$ (DMSO- $\left.d_{6}\right) \delta 163.20,162.91,155.67,131.27,131.01,130.93,130.85,129.53$, 127.86, 127.34, 125.68, 122.81, 122.39, 104.51, 101.07, 77.32, 37.63, 27.97, -0.37. LC-MS (ESI): $m / z 337.11$ $[\mathrm{M}-\mathrm{Boc}+\mathrm{H}]^{+}(100 \%)$. Analytical HPLC: $94 \%$ purity $(254 \mathrm{~nm})$.

\subsubsection{2-(2-Aminoethyl)-6-((trimethylsilyl)ethynyl)-1H-benzo[de]isoquinoline-1,3(2H)-dione (3)}

Compound $2(2.00 \mathrm{~g}, 4.58 \mathrm{mmol})$ was stirred in a 1:4 $(v / v)$ mixture of DCM and TFA at RT for $4 \mathrm{~h}$. The DCM and the bulk of the TFA were then removed in vacuo, leaving a thick orange liquid. Upon the addition of $\mathrm{H}_{2} \mathrm{O}(50 \mathrm{~mL})$, a yellow precipitate formed, which was collected via vacuum filtration, washed several times with cold $\mathrm{H}_{2} \mathrm{O}$ and dried in a vacuum desiccator overnight. Yield: $1.48 \mathrm{~g}, 96 \%$. ${ }^{1} \mathrm{H}-\mathrm{NMR}\left(400 \mathrm{MHz}\right.$, DMSO- $\left.d_{6}\right) \delta 8.50(\mathrm{ddd}, J=8.3,7.8,1.0 \mathrm{~Hz}, 2 \mathrm{H}), 8.36(\mathrm{~d}, J=7.6 \mathrm{~Hz}, 1 \mathrm{H}), 7.95(\mathrm{dt}$, $J=7.4,4.0 \mathrm{~Hz}, 2 \mathrm{H}), 4.30(\mathrm{t}, J=5.8 \mathrm{~Hz}, 2 \mathrm{H}), 3.26-3.06(\mathrm{~m}, 2 \mathrm{H}), 0.36(\mathrm{~s}, 9 \mathrm{H}) .{ }^{13} \mathrm{C}-\mathrm{NMR}(101 \mathrm{MHz}$, DMSO- $\left.d_{6}\right) \delta 163.70,163.41,131.55,131.32,131.13,130.90,129.80,128.34,127.31,125.79,122.78,122.37$, 105.07, 101.16, 37.61, 37.51, -0.25. LC-MS (ESI): $m / z 337.10[\mathrm{M}+\mathrm{H}]^{+}$. Analytical HPLC: 91\% purity $(254 \mathrm{~nm})$.

\subsubsection{2-Bromo-N-(2-(1,3-dioxo-6-((trimethylsilyl)ethynyl)-1H-benzo[delisoquinolin-2(3H)-yl)ethyl)acetamide (4)}

Compound $3(1.50 \mathrm{~g}, 4.46 \mathrm{mmol})$, bromoacetyl bromide $(1.80 \mathrm{~g}, 777 \mu \mathrm{L}, 8.92 \mathrm{mmol})$ and $\mathrm{Na}_{2} \mathrm{CO}_{3}$ $(1.42 \mathrm{~g}, 13.4 \mathrm{mmol})$ were dissolved in acetone $(50 \mathrm{~mL})$ and stirred at RT for $2 \mathrm{~h}$. The solvent was 
removed in vacuo to produce a brown solid. Purification via silica gel chromatography $(20 \%$ EtOAc in petroleum spirits) yielded the product as a pale yellow solid $\left(R_{\mathrm{f}}=0.1\right)$. Yield: $1.21 \mathrm{~g}, 59 \% .{ }^{1} \mathrm{H}-\mathrm{NMR}$ $\left(\right.$ DMSO- $\left._{6}\right) \delta 8.55-8.46(\mathrm{~m}, 2 \mathrm{H}), 8.36(\mathrm{dd}, J=7.6,3.2 \mathrm{~Hz}, 1 \mathrm{H}), 7.98-7.91(\mathrm{~m}, 2 \mathrm{H}), 4.13(\mathrm{t}, J=6.3 \mathrm{~Hz}, 2 \mathrm{H})$, $3.71(\mathrm{~d}, J=14.0 \mathrm{~Hz}, 2 \mathrm{H}), 3.54-3.34(\mathrm{~m}, 2 \mathrm{H}), 0.35(\mathrm{~s}, 9 \mathrm{H}) .{ }^{13} \mathrm{C}-\mathrm{NMR}$ (DMSO- $\left.d_{6}\right) \delta 131.63,131.45,131.23$, 130.12, 128.67, 127.62, 125.90, 125.81, 123.20, 123.10, 122.82, 122.70, 105.20, 105.12, 101.53, 61.66, 37.26, $36.67,29.64,0.06$. LC-MS (ESI): $m / z 457.00(100 \%)[\mathrm{M}+\mathrm{H}]^{+}$. Analytical HPLC: $97 \%$ purity $(254 \mathrm{~nm})$.

3.2.5. tri-tert-Butyl 2,2',2"-(10-(2-((2-(1,3-Dioxo-6-((trimethylsilyl)ethyn-yl)-1H-benzo[de]isoquinolin2(3H)-yl)ethyl)amino)-2-oxoethyl)-1,4,7,10-tetraazacyclododecane-1,4,7-triyl)triacetate (5)

Compound 4 (350 mg, $0.76 \mathrm{mmol}),{ }^{\mathrm{t}} \mathrm{Bu}_{3} \mathrm{DO}_{3} \mathrm{~A} . \mathrm{HBr}(414 \mathrm{mg}, 0.70 \mathrm{mmol})$, and DIPEA (180 mg, $242 \mu \mathrm{L}, 1.39 \mathrm{mmol})$ were dissolved in $\mathrm{ACN}(50 \mathrm{~mL})$ and the mixture refluxed overnight. The solvent was removed in vacuo and the residue subjected to silica gel chromatography ( $5 \% \mathrm{MeOH}$ in DCM) to isolate the product as a glassy yellow solid $\left(R_{\mathrm{f}}=0.1\right)$. Yield: $460 \mathrm{mg}, 81 \% .{ }^{1} \mathrm{H}-\mathrm{NMR}\left(\mathrm{CDCl}_{3}\right) \delta 8.56(\mathrm{dd}$, $J=8.4,1.1 \mathrm{~Hz}, 1 \mathrm{H}), 8.53(\mathrm{dd}, J=7.3,1.1 \mathrm{~Hz}, 1 \mathrm{H}), 8.41(\mathrm{~d}, J=7.6 \mathrm{~Hz}, 1 \mathrm{H}), 7.81(\mathrm{~d}, J=7.6 \mathrm{~Hz}, 1 \mathrm{H}), 7.76$ $(\mathrm{dd}, J=8.3,7.4 \mathrm{~Hz}, 1 \mathrm{H}), 4.37-1.97$ (broad set of overlapping signals, $28 \mathrm{H}), 1.42(\mathrm{~d}, J=2.9 \mathrm{~Hz}, 27 \mathrm{H})$, 0.33 (s, 9H). ${ }^{13} \mathrm{C}-\mathrm{NMR}\left(\mathrm{CDCl}_{3}\right) \delta 172.51,172.19,164.34,164.02,132.61,131.85,131.74,131.18,130.49$, 128.00, 127.61, 127.46, 122.75, 122.16, 105.53, 101.26, 81.86, 81.81, 56.49, 55.76, 54.23, 42.60, 39.61, 38.36, 28.24, 28.06, 27.99, -0.08. LC-MS (ESI): $m / z 446.47[\mathrm{M}+2 \mathrm{H}]^{2+}(100 \%)$. Analytical HPLC: $93 \%$ purity $(254 \mathrm{~nm})$.

3.2.6. 2,2',2"-(10-(2-((2-(6-Ethynyl-1,3-dioxo-1H-benzo[de]isoquinolin-2(3H)-yl)ethyl)amino)-2-oxoethyl)-1, 4,7,10-tetraazacyclododecane-1,4,7-triyl)triacetic acid (L)

Compound $5(320 \mathrm{mg}, 0.36 \mathrm{mmol})$ and $\mathrm{KF}(42 \mathrm{mg}, 0.72 \mathrm{mmol})$ were dissolved in 1:1 $(v / v)$ mixture of $\mathrm{H}_{2} \mathrm{O}$ and $\mathrm{ACN}(10 \mathrm{~mL})$ and the solution stirred for $3 \mathrm{~h}$ at RT. The solvent was removed in vacuo and the remaining residue dissolved in a 1:1 $(v / v)$ mixture of TFA and DCM and stirred O/N at RT. After removal of the TFA and DCM using a nitrogen stream, the crude product was purified by preparative HPLC. Lypholisation yielded a fluffy orange solid. Yield: $167 \mathrm{mg}, 71 \% .{ }^{1} \mathrm{H}-\mathrm{NMR}\left(\mathrm{CD}_{3} \mathrm{OD}\right) \delta 8.73(\mathrm{dd}$, $J=8.4,1.1 \mathrm{~Hz}, 1 \mathrm{H}), 8.62(\mathrm{dd}, J=7.3,1.1 \mathrm{~Hz}, 1 \mathrm{H}), 8.52(\mathrm{~d}, J=7.6 \mathrm{~Hz}, 1 \mathrm{H}), 8.00(\mathrm{~d}, J=7.6 \mathrm{~Hz}, 1 \mathrm{H})$, $7.93(\mathrm{dd}, J=8.4,7.4 \mathrm{~Hz}, 1 \mathrm{H}), 4.42(\mathrm{~s}, 1 \mathrm{H}), 4.49-3.00$ (broad set of overlapping signals, $28 \mathrm{H}) .{ }^{13} \mathrm{C}-\mathrm{NMR}$ $\left(\mathrm{CD}_{3} \mathrm{OD}\right) \delta 164.40,164.08,132.07,131.78,131.39,130.00,127.79,127.69,126.68,122.65,122.31,118.15$, 115.24, 39.21, 37.74. HRMS (ESI): $m / z$ calc'd for $[\mathrm{M}+\mathrm{H}]^{+}, \mathrm{M}=\mathrm{C}_{32} \mathrm{H}_{38} \mathrm{~N}_{6} \mathrm{O}_{9}: 651.2779$, found: 651.2773 . Analytical HPLC: $96 \%$ purity $(254 \mathrm{~nm})$.

\subsubsection{Gd-L}

Ligand L (38 mg, $47 \mu \mathrm{mol})$ and Gd(OAc) $)_{3}(39 \mathrm{mg}, 120 \mu \mathrm{mol})$ were dissolved in MilliQ $\mathrm{H}_{2} \mathrm{O}$ $(5 \mathrm{~mL})$ and the $\mathrm{pH}$ adjusted to $c a$. 7 with $2 \mathrm{M} \mathrm{NaOH}$. The resulting solution was stirred at $70{ }^{\circ} \mathrm{C}$ for $2 \mathrm{~h}$, after which time LC-MS showed complete complexation. The product was purified via preparative HPLC and isolated as a fluffy orange solid following lyophilisation. Yield: $20 \mathrm{mg}, 53 \%$. Anal. Calc'd for $\mathrm{C}_{32} \mathrm{H}_{35} \mathrm{~N}_{6} \mathrm{O}_{9} \mathrm{Gd} \cdot 6 \mathrm{H}_{2} \mathrm{O}: \mathrm{C}, 42.10 ; \mathrm{H}, 5.19 ; \mathrm{N}$, 9.20. Found: $\mathrm{C}, 42.09 ; \mathrm{H}, 5.06 ; \mathrm{N}, 9.11$. HRMS (ESI): $m / z$ calc'd for $[\mathrm{M}+\mathrm{H}]^{+}, \mathrm{M}=\mathrm{C}_{32} \mathrm{H}_{35} \mathrm{~N}_{6} \mathrm{O}_{9} \mathrm{Gd}: 806.1785$, found: 806.1779 . Analytical HPLC: $96 \%$ purity (254 nm).

\subsection{8. "Clicked" Gd-L}

Ligand L (38 mg, $47 \mu \mathrm{mol})$ and $\mathrm{Gd}(\mathrm{OAc})_{3}(39 \mathrm{mg}, 120 \mu \mathrm{mol})$ were dissolved in MilliQ $\mathrm{H}_{2} \mathrm{O}(5 \mathrm{~mL})$ and $\mathrm{pH}$ adjusted to $\mathrm{ca}$. 7 with $2 \mathrm{M} \mathrm{NaOH}$. The resulting solution was stirred at $70{ }^{\circ} \mathrm{C}$ for $2 \mathrm{~h}$. After this time, the $\mathrm{pH}$ of the solution was readjusted to $c a$. 7, then 3-azidopropan-1-ol (9.6 mg, $95 \mu \mathrm{mol})$, sodium ascorbate $(18.7 \mathrm{mg}, 95 \mu \mathrm{mol}), \mathrm{CuSO}_{4}(0.7 \mathrm{mg}, 5 \mu \mathrm{mol})$ and THPTA $(4.3 \mathrm{mg}, 10 \mu \mathrm{mol})$ added and the mixture stirred at RT O/N. The product was purified by preparative HLPC and isolated as a fluffy orange solid after lyophilisation. Yield: $20 \mathrm{mg}$, 47\%. Anal. Calc'd for $\mathrm{C}_{35} \mathrm{H}_{42} \mathrm{~N}_{9} \mathrm{O}_{10} \mathrm{Gd} \cdot 6 \mathrm{H}_{2} \mathrm{O}$ : 
C, 41.45; $\mathrm{H}, 5.37 ; \mathrm{N}, 12.43$. Found: $\mathrm{C}, 41.82 ; \mathrm{H}, 5.27 ; \mathrm{N}, 12.36$. HRMS (ESI): $m / z$ calc'd for $[\mathrm{M}+\mathrm{H}]^{+} \mathrm{M}=$ $\mathrm{C}_{35} \mathrm{H}_{42} \mathrm{~N}_{9} \mathrm{O}_{10} \mathrm{Gd}: 907.2374$, found: 907.2413 . Analytical HPLC: $96 \%$ purity (254 nm).

\subsubsection{Peptide Conjugation}

To a solution of Myr-Lys( $\left.\mathrm{N}_{3}\right)$-YGRKKRRQRRR [55] (10 mg, $\left.5.2 \mu \mathrm{mol}\right)$ in MilliQ water ( $\left.5 \mathrm{~mL}\right)$ was added Gd-L (10 mg, $12 \mu \mathrm{mol})$, followed by $\mathrm{CuSO}_{4}(0.8 \mathrm{mg}, 5 \mu \mathrm{mol})$, THPTA $(4.5 \mathrm{mg}, 10 \mu \mathrm{mol})$ and sodium ascorbate $(3.1 \mathrm{mg}, 16 \mu \mathrm{mol})$. The $\mathrm{pH}$ was then adjusted to $6-7$ with $1 \mathrm{M} \mathrm{HCl}$ and the mixture stirred O/N at RT. Peptide LC-MS analysis showed near-complete consumption of starting peptide after this time. The product was isolated as a white solid following preparative HPLC and lyophilisation. Peptide LC-MS (ESI): $m / z 986.95[\mathrm{M}+2 \mathrm{TFA}+\mathrm{H}]^{3+}, 90 \%$ purity $(214 \mathrm{~nm})$.

\subsection{Quantum Yield Determinations}

Complexes were prepared at a range on concentrations in a $100 \mathrm{mM}$ HEPES buffer at $\mathrm{pH} 7.4$, and absorbance and fluorescence emission spectra recorded. Quantum yields $(\Phi)$ were then determined, using quinine sulphate in $0.1 \mathrm{M}$ sulfuric acid as the reference compound $(\Phi=54 \%)$ [80], according to the following equation:

$$
\Phi_{\mathrm{X}}=\Phi_{\mathrm{ST}} \times\left(\operatorname{Grad}_{\mathrm{X}} / \operatorname{Grad}_{\mathrm{ST}}\right) \times\left(\eta_{\mathrm{X}} / \eta_{\mathrm{ST}}\right)^{2}
$$

where $\Phi$ is the quantum yield, $\mathrm{X}$ and ST denote the sample and reference, respectively, Grad is the gradient of the integrated fluorescence $v s$. absorbance plot, and $\eta$ represents the refractive index of the solvent.

\subsection{Cell Culture}

Tongue squamous carcinoma cells (CAL-33) were cultured in phenol red-free RPMI medium

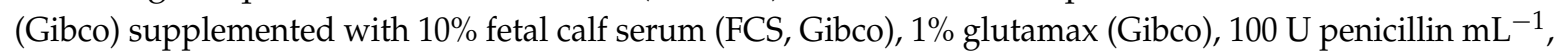
$100 \mu \mathrm{g}$ streptomycin $\mathrm{mL}^{-1}$ at $37^{\circ} \mathrm{C}$ and $6 \% \mathrm{CO}_{2}$.

\subsection{Cytotoxicity Studies}

Cytotoxicity studies of the effect of irradiation on CAL-33 cells treated with Gd-L, "clicked" Gd-L and the Gd-L-Tat peptide conjugate were performed via a fluorimetric cell viability assay using resazurin (Promocell $\mathrm{GmbH}$ ). Briefly, one day before treatment, cells were plated in triplicate into 96-well plates at a density of $4 \times 10^{3}$ cells. $^{\text {well }}{ }^{-1}$ in $100 \mu \mathrm{L}$ of medium. After addition of increasing concentrations of the test compound, cells were incubated for $4 \mathrm{~h}$, then the medium was replaced with fresh medium devoid of compound. The plates were irradiated for $10 \mathrm{~min}$ at $350 \mathrm{~nm}\left(2.58 \mathrm{~J} \cdot \mathrm{cm}^{-2}\right)$ in a Rayomet Chamber Reactor. Upon further incubation at $37^{\circ} \mathrm{C}$ in $6 \% \mathrm{CO}_{2}$ for $44 \mathrm{~h}$, the medium was removed and complete medium $(100 \mu \mathrm{L})$ containing resazurin $\left(0.2 \mathrm{mg} \cdot \mathrm{mL}^{-1}\right.$ final concentration) was added. After $4 \mathrm{~h}$ of incubation at $37{ }^{\circ} \mathrm{C}$ in $6 \% \mathrm{CO}_{2}$, the fluorescence of the intensely red fluorescent resorufin product was quantified using a SpectraMax M5 microplate reader (excitation: $540 \mathrm{~nm}$; emission: $590 \mathrm{~nm}$ ).

\subsection{Cellular Uptake Studies}

Cellular uptake and localisation of Gd-L, "clicked" Gd-L and the Gd-L-Tat peptide conjugate was assessed by confocal fluorescence microscopy. CAL-33 cells were grown on 18-mm Menzel-gläser coverslips at a density of $2 \times 10^{5}$ cells. $\mathrm{mL}^{-1}$ and incubated for $4 \mathrm{~h}$ with one of the compounds $(100 \mu \mathrm{M})$. Cells were fixed in $4 \%$ formaldehyde in phosphate-buffered saline (PBS), washed with PBS and $\mathrm{H}_{2} \mathrm{O}$, and mounted on slides for viewing. Fixed cells were viewed on a CLSM Leica SP5 microscope (Heerbrugg, Switzerland), with the compounds visualised using the hybrid 1 red wavelength selection on the microscope (excitation: $405 \mathrm{~nm}$; emission: $600-800 \mathrm{~nm}$ ). It should be noted that there is the possibility that fixation may change the cellular localisation of fluorescent molecules as they may be washed out or redistributed. 


\section{Conclusions}

In conclusion, we have developed a new Gd(III)-DOTA-naphthalimide complex that can be readily conjugated to azide-bearing molecules via the $\mathrm{Cu}(\mathrm{I})$-catalysed click reaction to introduce a fluorescent and photo-cytotoxic label. Whilst the photo-physical properties of the naphthalimide group are not optimal for PDT, the complex represents a useful prototype building block for the facile construction of new theranostic agents for combined PDT and optical imaging. By virtue of the Gd centre, the complex could also serve as an effective MRI contrast agent if incorporated into appropriate in vivo imaging agent designs. Future work will include measurement of the proton nuclear magnetic relaxation dispersion of the "clicked" Gd-L complex to confirm this capability. Since MRI is a very insensitive technique, it will also be important to establish conjugate designs that are able to deliver sufficient concentrations of Gd-L to desired sites (e.g., diseased tissue) to provide adequate image contrast in vivo.

Supplementary Materials: The following are available online at http:/ /www.mdpi.com/1420-3049/21/2/194/s1. NMR spectra of reported compounds, LC traces for final ligand, Gd(III) complexes and peptide conjugate.

Acknowledgments: Financial support by the Australian Research Council (DP120100561, DP150100383 and FT130100838 to B.G., and DP130100816 to L.S.), the Swiss National Science Foundation (Professorships ${ }^{\circ}$ PP00P2_133568 and PP00P2_157545 to G.G.), the Stiftung für Wissenschaftliche Forschung of the University of Zurich (G.G.), the UBS Promedica Stiftung (R.R. and G.G.), the Novartis Jubilee Foundation (R.R. and G.G.) and the University of Zurich (G.G.) is gratefully acknowledged. The authors thank the Center for Microscopy and Image Analysis of the University of Zurich for access to state-of-the-art equipment.

Author Contributions: M.R.G., L.S., K.L.T., G.G. and B.G. conceived and designed the experiments; W.O., R.R. and M.L.A. performed the experiments; W.O., R.R., M.R.G., L.S., K.L.T., G.G. and B.G. analyzed the data; W.O., R.R., L.S., K.L.T., G.G. and B.G. wrote the paper.

Conflicts of Interest: The authors declare no conflict of interest.

\section{Abbreviations}

The following abbreviations are used in this manuscript:

$\begin{array}{ll}\text { ACN: } & \text { acetonitrile } \\ \text { BOC: } & \text { tert-butoxycarbonyl } \\ { }^{t} \mathrm{Bu}_{3} \text { DO3A: } & \text { tert-butyl-protected 1,4,7,10-tetraazacyclodocane-1,4,7,10-tetraacetic acid } \\ \mathrm{d}: & \text { doublet } \\ \mathrm{dd}: & \text { doublet of doublets } \\ \mathrm{ddd}: & \text { doublet of doublet of doublets } \\ \mathrm{dt}: & \text { doublet of triplets } \\ \text { DCM: } & \text { dichloromethane } \\ \text { DIC: } & \text { differential interference contrast } \\ \text { DIPEA: } & \text { N,N-diisopropylethylamine } \\ \text { DMF: } & \text { N,N-dimethylformamide } \\ \text { DOTA: } & \text { 1,4,7,10-tetraazacyclodocane-1,4,7,10-tetraacetic acid } \\ \text { ESI: } & \text { electrospray ionization } \\ \text { HEPES: } & \text { 4-(2-hydroxyethyl)-1-piperazineethanesulfonic acid } \\ \text { HPLC: } & \text { high-performance liquid chromatography } \\ \text { HRMS: } & \text { high-resolution mass spectrometry } \\ \text { IC } 50 & \text { half maximal inhibitory concentration } \\ \text { J: } & \text { coupling constant } \\ \text { LC-MS: } & \text { liquid chromatography-mass spectrometry } \\ \text { m: } & \text { multiplet } \\ \text { MRI: } & \text { magnetic resonance imaging } \\ \text { NMR: } & \text { nuclear magnetic resonance NMR }\end{array}$




$\begin{array}{ll}\text { O/N: } & \text { overnight } \\ \text { PBS: } & \text { phosphate-buffered saline } \\ \text { PDT: } & \text { photo-dynamic therapy } \\ \text { PI: } & \text { photo-toxic index } \\ \text { RT: } & \text { room temperature } \\ R_{\mathrm{f}}: & \text { retention factor } \\ \text { S: } & \text { singlet } \\ \text { SPAAC: } & \text { strain-promoted azide-alkyne cycloaddition } \\ \text { t: } & \text { triplet } \\ \text { TAT: } & \text { trans-activator of transcription } \\ \text { THF: } & \text { tetrahydrofuran } \\ \text { TFA: } & \text { trifluoroacetic acid } \\ \text { THPTA: } & \text { tris(3-hydroxypropyl-triazolylmethyl)amine } \\ \text { TLC: } & \text { thin layer chromatography } \\ \text { TMS: } & \text { trimethylsilyl } \\ \text { UV-A: } & \text { ultraviolet A radiation } \\ \text { Ф: } & \text { quantum yield }\end{array}$

\section{References}

1. Lee, S.Y.; Jeon, S.I.; Jung, S.; Chung, I.J.; Ahn, C.-H. Targeted multimodal imaging modalities. Adv. Drug Del. Rev. 2014, 76, 60-78. [CrossRef] [PubMed]

2. Melendez-Alafort, L.; Muzzio, P.C.; Rosato, A. Optical and multimodal peptide-based probes for in vivo molecular imaging. Anticancer Agents Med. Chem. 2012, 12, 476-499. [CrossRef] [PubMed]

3. Kobayashi, H.; Longmire, M.R.; Ogawa, M.; Choyke, P.L. Rational chemical design of the next generation of molecular imaging probes based on physics and biology: Mixing modalities, colors and signals. Chem. Soc. Rev. 2011, 40, 4626-4648. [CrossRef] [PubMed]

4. Louie, A. Multimodality imaging probes: Design and challenges. Chem. Rev. 2010, 10, 3146-3195. [CrossRef] [PubMed]

5. Jennings, L.E.; Long, N.J. "Two is better than one"-Probes for dual-modality molecular imaging. Chem. Commun. 2009, 3511-3524. [CrossRef] [PubMed]

6. Fass, L. Imaging and cancer: A review. Mol. Oncol. 2008, 2, 115-152. [CrossRef] [PubMed]

7. Glasspool, R.M.; Evans, T.R. Clinical imaging of cancer metastasis. Eur. J. Cancer 2000, 36, 1661-1670. [CrossRef]

8. Palekar-Shanbhag, P.; Jog, S.V.; Chogale, M.M.; Gaikwad, S.S. Theranostics for cancer therapy. Curr. Drug Deliv. 2013, 10, 357-362. [CrossRef] [PubMed]

9. Lammers, T.; Rizzo, L.Y.; Storm, G.; Kiessling, F. Personalized nanomedicine. Clin. Cancer Res. 2012, 18, 4889-4894. [CrossRef] [PubMed]

10. Kelkar, S.S.; Reineke, T.M. Theranostics: Combining imaging and therapy. Bioconjugate Chem. 2011, 22, 1879-1903. [CrossRef] [PubMed]

11. Kumar, R.; Shin, W.S.; Sunwoo, K.; Kim, W.Y.; Koo, S.; Bhuniya, S.; Kim, J.S. Small conjugate-based theranostic agents: An encouraging approach for cancer therapy. Chem. Soc. Rev. 2015, 44, 6670-6683. [CrossRef] [PubMed]

12. Lim, E.-K.; Kim, T.; Paik, S.G.; Haam, S.; Huh, Y.-M.; Lee, K. Nanomaterials for theranostics: Recent advances and future challenges. Chem. Rev. 2015, 115, 327-394. [CrossRef] [PubMed]

13. Muthu, M.S.; Leong, D.T.; Mei, L.; Feng, S.-S. Nanotheranostics-Application and further development of nanomedicine strategies for advanced theranostics. Theranostics 2014, 4, 660-677. [CrossRef] [PubMed]

14. Wang, Y.; Shim, M.S.; Levinson, N.S.; Sung, H.-W.; Xia, Y. Stimuli-responsive materials for controlled release of theranostic agents. Adv. Funct. Metar. 2014, 24, 4206-4220. [CrossRef] [PubMed] 
15. Caldorera-Moore, M.E.; Liechty, W.B.; Peppas, N.A. Responsive theranostic systems: Integration of diagnostic imaging agents and responsive controlled release drug delivery carriers. Acc. Chem. Res. 2011, 44, 1061-1070. [CrossRef] [PubMed]

16. Bansal, A.; Zhang, Y. Photocontrolled nanoparticle delivery systems for biomedical applications. Acc. Chem. Res. 2014, 47, 3052-3060. [CrossRef] [PubMed]

17. Salvatore, S. Photoactivated nanomaterials for biomedical release applications. J. Mater. Chem. 2012, 22, 301-318.

18. Rai, P.; Mallidi, S.; Zheng, X.; Rahmanzadeh, R.; Mir, Y.; Elrington, S.; Khurshid, A.; Hasan, T. Development and applications of photo-triggered theranostic agents. Adv. Drug Deliv. Rev. 2010, 62, 1094-1124. [CrossRef] [PubMed]

19. Schmitt, J.; Heitz, V.; Sour, A.; Bolze, F.; Kessler, P.; Flamigni, L.; Ventura, B.; Bonnet, C.S.; Tóth, E. A theranostic agent combining a two-photon-absorbing photosensitizer for photodynamic therapy and a gadolinium(III) complex for MRI detection. Chem. Eur. J. 2016. [CrossRef] [PubMed]

20. Dixit, S.; Novak, T.; Miller, K.; Zhu, Y.; Kenney, M.E.; Broome, A.M. Transferrin receptor-targeted theranostic gold nanoparticles for photosensitizer delivery in brain tumors. Nanoscale 2015, 7, 1782-1790. [CrossRef] [PubMed]

21. Truillet, C.; Lux, F.; Moreau, J.; Four, M.; Sancey, L.; Chevreux, S.; Boeuf, G.; Perriat, P.; Frochot, C.; Antoine, R.; et al. Bifunctional polypyridyl-Ru(II) complex grafted onto gadolinium-based nanoparticles for MR-imaging and photodynamic therapy. Dalton Trans. 2013, 42, 12410-12420. [CrossRef] [PubMed]

22. Cao, Y.; Pan, R.; Xuan, W.; Wei, Y.; Liu, K.; Zhou, J.; Wang, W. Photo-triggered fluorescent theranostic prodrugs as DNA alkylating agents for mechlorethamine release and spatiotemporal monitoring. Org. Biomol. Chem. 2015, 13, 6742-6748. [CrossRef] [PubMed]

23. Karaoun, N.; Renfrew, A.K. A luminescent ruthenium(II) complex for light-triggered drug release and live cell imaging. Chem. Commun. 2015, 14038-14041. [CrossRef] [PubMed]

24. Knoll, J.D.; Turro, C. Control and utilization of ruthenium and rhodium metal complex excited states for photoactivated cancer therapy. Coord. Chem. Rev. 2015, 282, 110-126. [CrossRef] [PubMed]

25. Mari, C.; Pierroz, V.; Leonidova, A.; Ferrari, S.; Gasser, G. Towards selective light-activated Ru ${ }^{\mathrm{II}}$-based prodrug candidates. Eur. J. Inorg. Chem. 2015, 23, 3879-3891. [CrossRef]

26. Leonidova, A.; Pierroz, V.; Rubbiani, R.; Lan, Y.; Schmitz, A.G.; Kaech, A.; Sigel, R.K.O.; Ferrari, S.; Gasser, G. Photo-induced uncaging of a specific $\operatorname{Re}(\mathrm{I})$ organometallic complex in living cells. Chem. Sci. 2014, 5, 4044-4056. [CrossRef]

27. Dai, Y.; Xiao, H.; Liu, J.; Yuan, Q.; Ma, P.A.; Yang, D.; Li, C.; Cheng, Z.; Hou, Z.; Yang, P.; et al. In vivo multimodality imaging and cancer therapy by near-infrared light-triggered trans-platinum pro-drug-conjugated upconverison nanoparticles. J. Am. Chem. Soc. 2013, 135, 18920-18929. [CrossRef] [PubMed]

28. Shi, G.; Monro, S.; Hennigar, R.; Colpitts, J.; Fong, J.; Kasimova, K.; Yin, H.; DeCoste, R.; Spencer, C.; Chamberlain, L.; et al. Ru(II) dyads derived from $\alpha$-oligothiophenes: A new class of potent and versatile photosensitizers for PDT. Coord. Chem. Rev. 2015, 282, 127-138. [CrossRef]

29. Ma, D.-L.; He, H.-Z.; Leung, K.-H.; Chan, D.S.-H.; Leung, C.-H. Bioactive luminescent transition-metal complexes for biomedical applications. Angew. Chem. Int. Ed. 2013, 52, 7666-7682. [CrossRef] [PubMed]

30. Yua, A.; Wu, J.; Tang, X.; Zhao, L.; Xu, F.; Hu, Y. Application of near-infrared dyes for tumor imaging, photothermal, and photodynamic therapies. J. Pharm. Sci. 2013, 102, 6-28.

31. Meldal, M.; Tornø, C.W. Cu-catalyzed azide-alkyne cycloaddition. Chem. Rev. 2008, 108, $2952-3015$. [CrossRef] [PubMed]

32. Kolb, H.C.; Finn, M.G.; Sharpless, K.B. Click chemistry: Diverse chemical function from a few good reactions. Angew. Chem. Int. Ed. 2001, 40, 2004-2021. [CrossRef]

33. Jewett, J.C.; Bertozzi, C.R. Cu-free click cycloaddition reactions in chemical biology. Chem. Soc. Rev. 2010, 39, 1272-1279. [CrossRef] [PubMed]

34. Baskin, J.M.; Prescher, J.A.; Laughlin, S.T.; Agard, N.J.; Chang, P.V.; Miller, I.A.; Lo, A.; Codelli, J.A.; Bertozzi, C.R. Copper-free click chemistry for dynamic in vivo imaging. Proc. Natl. Acad. Sci. USA 2007, 104, 16793-16797. [CrossRef] [PubMed] 
35. Kim, H.L.; Sachin, K.; Jeong, H.J.; Choi, W.; Lee, H.S.; Kim, D.W. F-18 labeled RGD probes based on bioorthogonal strain-promoted click reaction for PET imaging. ACS Med. Chem. Lett. 2015, 6, 402-407. [CrossRef] [PubMed]

36. Li, G.; Xing, Y.; Wang, J.; Conti, P.S.; Chen, K. Near-infrared fluorescence imaging of CD13 receptor expression using a novel Cy5.5-labeled dimeric NGR peptide. Amino Acids 2014, 46, 1547-1556. [CrossRef] [PubMed]

37. Zeng, D.; Zeglis, B.M.; Lewis, J.S.; Anderson, C.J. The growing impact of bioorthogonal click chemistry on the development of radiopharmaceuticals. J. Nucl. Med. 2013, 54, 829-832. [CrossRef] [PubMed]

38. Chen, K.; Wang, X.; Lin, W.-Y.; Shen, C.K.-F.; Yap, L.-P.; Hughes, L.D.; Conti, P.S. Strain-promoted catalyst-free click chemistry for rapid construction of ${ }^{64} \mathrm{Cu}$-labeled PET imaging probes. ACS Med. Chem. Lett. 2012, 3, 1019-1023. [CrossRef] [PubMed]

39. Lee, D.E.; Na, J.H.; Lee, S.; Kang, C.M.; Kim, H.N.; Han, S.J.; Kim, H.; Choe, Y.S.; Jung, K.H.; Lee, K.C.; et al. Facile method to radiolabel glycol chitosan nanoparticles with ${ }^{64} \mathrm{Cu}$ via copper-free click chemistry for MicroPET imaging. Mol. Pharm. 2013, 10, 2190-2198. [CrossRef] [PubMed]

40. Zhang, P.; Liu, S.; Gao, D.; Hu, D.; Gong, P.; Sheng, Z.; Deng, J.; Ma, Y.; Cai, L. Click-functionalized compact quantum dots protected by multidentate-imidazole ligands: Conjugation-ready nanotags for living-virus labeling and imaging. J. Am. Chem. Soc. 2012, 134, 8388-8391. [CrossRef] [PubMed]

41. Das, M.; Bandyopadhyay, D.; Mishra, D.; Datir, S.; Dhak, P.; Jain, S.; Maiti, T.K.; Basak, A.; Pramanik, P. "Clickable”, trifunctional magnetite nanoparticles and their chemoselective biofunctionalization. Bioconjugate Chem. 2011, 22, 1181-1193. [CrossRef] [PubMed]

42. Beal, D.M.; Albrow, V.E.; Burslem, G.; Hitchen, L.; Fernandes, C.; Lapthorn, C.; Roberts, L.R.; Selby, M.D.; Jones, L.H. Click-enabled heterotrifunctional template for sequential bioconjugations. Org. Biomol. Chem. 2012, 10, 548-554. [CrossRef] [PubMed]

43. Clavé, G.; Volland, H.; Flaender, M.; Gasparutto, D.; Romieu, A.; Renard, P.-Y. A universal and ready-to-use heterotrifunctional cross-linking reagent for facile synthetic access to sophisticated bioconjugates. Org. Biomol. Chem. 2010, 8, 4329-4345. [CrossRef] [PubMed]

44. Ornelas, C.; Weck, M. Construction of well-defined multifunctional dendrimers using a trifunctional core. Chem. Commun. 2009, 5710-5712. [CrossRef] [PubMed]

45. Mari, C.; Pierroz, V.; Ferrari, S.; Gasser, G. Combination of Ru(II) complexes and light: New frontiers in cancer therapy. Chem. Sci. 2015, 6, 2660-2686. [CrossRef]

46. Antoni, P.M.; Naik, A.; Albert, I.; Rubbiani, R.; Gupta, S.; Ruiz-Sánchez, P.; Munikorn, P.; Mateos, J.M.; Luginbuehl, V.; Thamyongkit, P.; et al. (Metallo) porphyrins as potent phototoxic anti-cancer agents after irradiation with red light. Chem. Eur. J. 2015, 21, 1179-1183. [CrossRef] [PubMed]

47. Mion, G.; Gianferrara, T.; Bergamo, A.; Gasser, G.; Pierroz, V.; Rubbiani, R.; Vilar, R.; Leczkowska, A.; Alessio, E. Phototoxic activity and DNA interactions of water-soluble porphyrins and their rhenium(I) conjugates. ChemMedChem 2015, 10, 1901-1914. [CrossRef] [PubMed]

48. Gianferrara, T.; Spagnul, C.; Alberto, R.; Gasser, G.; Ferrari, S.; Pierroz, V.; Bergamo, A.; Alessio, E. Towards matched pairs of porphyrin- $\mathrm{Re}^{\mathrm{I}} / 99 \mathrm{~m} \mathrm{Tc}^{\mathrm{I}}$ conjugates that combine photodynamic activity with fluorescence and radio imaging. ChemMedChem 2014, 9, 1231-1237. [CrossRef] [PubMed]

49. Frei, A.; Rubbiani, R.; Tubafard, S.; Blacque, O.; Anstaett, P.; Felgenträger, A.; Maisch, T.; Spiccia, L.; Gasser, G. Synthesis, characterization, and biological evaluation of new Ru(II) polypyridyl photosensitizers for photodynamic therapy. J. Med. Chem. 2014, 57, 7280-7292. [CrossRef] [PubMed]

50. Mari, C.; Pierroz, V.; Rubbiani, R.; Patra, M.; Hess, J.; Spingler, B.; Oehninger, L.; Schur, J.; Ott, I.; Salassa, L.; et al. DNA intercalating $\mathrm{Ru}^{\mathrm{II}}$ polypyridyl complexes as effective photosensitizers in photodynamic therapy. Chem. Eur. J. 2014, 44, 14421-14436. [CrossRef] [PubMed]

51. Leonidova, A.; Pierroz, V.; Rubbiani, R.; Heier, J.; Ferrari, S.; Gasser, G. Towards cancer cell-specific phototoxic organometallic rhenium(I) complexes. Dalton Trans. 2014, 43, 4287-4294. [CrossRef] [PubMed]

52. Naik, A.; Rubbiani, R.; Gasser, G.; Spingler, B. Visible-light-induced annihilation of tumor cells with platinum-porphyrin conjugates. Angew. Chem. Int. Ed. 2014, 53, 6938-6941. [CrossRef] [PubMed]

53. Gasser, G.; Hüsken, N.; Köster, S.D.; Metzler-Nolte, N. Synthesis of organometallic PNA oligomers by click chemistry. Chem. Commun. 2008, 3675-3677. [CrossRef] [PubMed]

54. Gasser, G.; Pinto, A.; Neumann, S.; Sosniak, A.M.; Seitz, M.; Merz, K.; Heumann, R.; Metzler-Nolte, N. Synthesis, characterisation and bioimaging of a fluorescent rhenium-containing PNA bioconjugate. Dalton Trans. 2012, 41, 2304-2313. [CrossRef] [PubMed] 
55. Leonidova, A.; Pierroz, V.; Adams, L.A.; Barlow, N.; Ferrari, S.; Graham, B.; Gasser, G. Enhanced cytotoxicity through conjugation of a "clickable" luminescent Re(I) complex to a cell-penetrating lipopeptide. ACS Med. Chem. Lett. 2014, 5, 809-814. [CrossRef] [PubMed]

56. Viehweger, K.; Barbaro, L.; Pombo García, K.; Joshi, T.; Geipel, G.; Steinbach, J.; Stephan, H.; Spiccia, L.; Graham, B. EGF receptor-targeting peptide conjugate incorporating a near-IR fluorescent dye and a novel 1, 4, 7-triazacyclononane-based ${ }^{64} \mathrm{Cu}$ (II) chelator assembled via click chemistry. Bioconjugate Chem. 2014, 25, 1011-1022. [CrossRef] [PubMed]

57. Choy, T.H.; Ozawa, K.; Tuck, K.L.; Barlow, N.; Huber, T.; Otting, G.; Graham, B. Lanthanide tags for site-specific ligation to an unnatural amino acid and generation of pseudocontact shifts in proteins. Bioconjugate Chem. 2013, 24, 260-268.

58. Loh, C.-T.; Graham, B.; Abdelkader, E.H.; Tuck, K.L.; Otting, G. Generation of pseudocontact shifts in proteins with lanthanides using small "clickable" nitrilotriacetic acid and iminodiacetic acid tags. Chem. Eur. J. 2015, 21, 5084-5092. [CrossRef] [PubMed]

59. Abdelkader, E.H.; Feintuch, A.; Yao, X.; Adams, L.A.; Aurelio, L.; Graham, B.; Goldfarb, D.; Otting, G. Protein conformation by EPR spectroscopy using gadolinium tags clicked to genetically encoded p-azido-L-phenylalanine. Chem. Commun. 2015, 15898-15901. [CrossRef] [PubMed]

60. Choi, W.-T.; Liu, H.-W.; Lo, K.K.-W. Rhenium(I) polypyridine dibenzocyclooctyne complexes as phosphorescent bioorthogonal probes: Synthesis, characterization, emissive behavior, and biolabeling properties. J. Inorg. Biochem. 2015, 148, 2-10. [CrossRef] [PubMed]

61. Candelon, N.; Hadade, N.D.; Matache, M.; Canet, J.-L.; Cisnetti, F.; Funeriu, D.P.; Nauton, L.; Gautier, A. Luminogenic "clickable" lanthanide complexes for protein labelling. Chem. Commun. 2013, 49, 9206-9208. [CrossRef] [PubMed]

62. Mastarone, D.J.; Harrison, V.S.R.; Eckermann, A.L.; Parigi, G.; Luchinat, C.; Meade, T.J. A modular system for the synthesis of multiplexed magnetic resonance probes. J. Am. Chem. Soc. 2011, 133, 5329-5337. [CrossRef] [PubMed]

63. Lebedev, A.Y.; Holland, J.P.; Lewis, J.S. Clickable bifunctional radiometal chelates for peptide labelling. Chem. Commun. 2010, 46, 1706-1708. [CrossRef] [PubMed]

64. Mindt, T.L.; Struthers, H.; Brans, L.; Anguelov, T.; Schweinsberg, C.; Maes, V.; Tourwé, D.; Schibli, R. “Click to chelate": Synthesis and installation of metal chelates into biomolecules in a single step. J. Am. Chem. Soc. 2006, 128, 15096-15097. [CrossRef] [PubMed]

65. Abraham, B.; Kelly, L.A. Photooxidation of amino acids and proteins mediated by novel 1,8-naphthalimide derivatives. J. Phys. Chem. B 2003, 107, 12534-12541. [CrossRef]

66. Zhang, J.; Woods, R.J.; Brown, P.B.; Lee, K.D.; Kane, R.R. Synthesis and photochemical protein crosslinking studies of hydrophilic naphthalimides. Bioorg. Med. Chem. Lett. 2002, 12, 853-856. [CrossRef]

67. Rogers, J.A.; Weiss, S.J.; Kelly, L.A. Photoprocesses of naphthalene imide and diimide derivatives in aqueous solutions of DNA. J. Am. Chem. Soc. 2000, 122, 427-436. [CrossRef]

68. Aveline, B.A.; Matsugo, S.; Redmond, R.W. Photochemical mechanisms responsible for the versatile application of naphthalimides and naphthaldiimides in biological systems. J. Am. Chem. Soc. 1997, 119, 11785-11795. [CrossRef]

69. Saito, I.; Takayama, M.; Sugiyama, H.; Nakatani, K. Photoinduced DNA cleavage via electron transfer: Demonstration that guanine residues located $5^{\prime}$ to guanine are the most electron-donating sites. J. Am. Chem. Soc. 1995, 117, 6406-6407. [CrossRef]

70. Saito, I.; Takayama, M. Photoactivatable DNA-cleaving amino acids: Highly sequence-selective DNA photocleavage by novel L-lysine derivatives. J. Am. Chem. Soc. 1995, 117, 5590-5591. [CrossRef]

71. Matsugo, S.; Kawanishi, S.; Yamamoto, K.; Sugiyama, H.; Matsuura, T.; Saito, I. Bis(hydroperoxy)naphthaldiimide as a "photo-Fenton reagent": Sequence-specific photocleavage of DNA. Angew. Chem. Int. Ed. 1991, 30, 1351-1353. [CrossRef]

72. Stasiuk, G.J.; Long, N.J. The ubiquitous DOTA and its derivatives: The impact of 1,4,7,10tetraazacyclododecane-1,4,7,10-tetraacetic acid on biomedical imaging. Chem. Commun. 2013, 49, 2732-2746. [CrossRef] [PubMed]

73. Caravan, P.; Ellison, J.; McMurry, T.; Lauffer, R. Gadolinium(III) chelates as MRI contrast agents: Structure, dynamics, and applications. Chem Rev. 1999, 99, 2293-2352. [CrossRef] [PubMed] 
74. Sherry, A.D.; Caravan, P.; Lenkinski, R.E. Primer on gadolinium chemistry. Magn. Reson. Med. 2009, 30, 1240-1248. [CrossRef] [PubMed]

75. Vives, E.; Brodin, P.; Lebleu, B. A truncated HIV-1 Tat protein basic domain rapidly translocates through the plasma membrane and accumulates in the cell nucleus. J. Biol. Chem. 1997, 272, 16010-16017. [CrossRef] [PubMed]

76. Raghunand, N.; Guntle, G.P.; Gokhale, V.; Nichol, G.S.; Mash, E.A.; Jagadish, B. Design, synthesis, and evaluation of 1,4,7,10-tetraazacyclododecane-1,4,7-triacetic acid derived, redox-sensitive contrast agents for magnetic resonance imaging. J. Med. Chem. 2010, 53, 6747-6757. [CrossRef] [PubMed]

77. Cha, T.R.; Hilgraf, R.; Sharpless, K.B.; Fokin, V.V. Polytriazoles as copper(I)-stabilizing ligands in catalysis. Org. Lett. 2004, 6, 2853-2855.

78. Hong, V.; Presolski, S.I.; Ma, C.; Finn, M.G. Analysis and optimization of copper-catalyzed azide-alkyne cycloaddition for bioconjugation. Angew. Chem. Int. Ed. 2009, 48, 9879-9883. [CrossRef] [PubMed]

79. Sawa, M.; Hsu, T.-L.; Itoh, T.; Sugiyama, M.; Hanson, S.R.; Vogt, P.K.; Wong, C.-H. Glycoproteomic probes for fluorescent imaging of fucosylated glycans in vivo. Proc. Natl. Acad. Sci. USA 2006, 103, 12371-12376. [CrossRef] [PubMed]

80. Melhuish, W.H. Quantum efficiencies of fluorescence of organic substances: Effect of solvent and concentration of the fluorescent solute. J. Phys. Chem. 1961, 65, 229-235. [CrossRef]

81. Sturzu, A.; Klose, U.; Echner, H.; Beck, A.; Gharabaghi, A.; Kalbacher, H.; Heckl, S. Cellular uptake of cationic gadolinium-DOTA peptide conjugates with and without $N$-terminal myristoylation. Amino Acids 2009, 37, 249-255. [CrossRef] [PubMed]

Sample Availability: Not available.

(C) 2016 by the authors; licensee MDPI, Basel, Switzerland. This article is an open access article distributed under the terms and conditions of the Creative Commons by Attribution (CC-BY) license (http:/ / creativecommons.org/licenses/by/4.0/). 